\title{
Environmental effects of mosquito insecticides on saltmarsh invertebrate fauna
}

\author{
Tanya L. Russell ${ }^{1,2,3,4, *}$, Brian H. Kay ${ }^{1}$, Greg A. Skilleter ${ }^{2}$ \\ ${ }^{1}$ Queensland Institute of Medical Research (QIMR) and Australian Centre for International and Tropical Health, \\ P. O. Royal Brisbane Hospital, Brisbane, Queensland 4029, Australia \\ ${ }^{2}$ Marine and Estuarine Ecology Unit, School of Integrative Biology, University of Queensland (UQ), Brisbane, \\ Queensland, 4072, Australia
}

Present address: ${ }^{3}$ Public Health Entomology Unit, Ifakara Health Institute, PO Box 53, Ifakara, Kilombero, United Republic of Tanzania and ${ }^{4}$ Vector Group, Liverpool School of Tropical Medicine, Pembroke Place, Liverpool L3 5QA, United Kingdom

\begin{abstract}
Despite the fact that Bacillus thuringiensis var. israelensis de Barjac (Bti) and s-methoprene are considered to be among the most target-specific of insecticides, there are some indications that non-target organisms may be impacted in different ecosystems. We examined the effects of Bti and $s$-methoprene on non-target aquatic and terrestrial fauna in 2 subtropical saltmarshes approximately $30 \mathrm{~km}$ apart. The main taxa collected from ephemeral pools were copepods and from terrestrial plots were springtails (Collembola), mites (Acariformes) and ants (Hymenoptera), with smaller numbers of beetles (Coleoptera), true bugs (Heteroptera) and flies (Diptera). Following applications of both products, inconsistent short-term $(<20 \mathrm{~d})$ differences in the composition of the arthropod community were noted. After applications of Bti to ephemeral pools, smaller numbers of copepods were recorded but at only one locality. There were no significant effects of $s$-methoprene on the arthropods in ephemeral pools at either locality. The numbers of mites increased in terrestrial plots after applications of $s$-methoprene at both localities and Bti at one locality, but these effects were short-lived and varied depending on which specific habitat was sampled (i.e. vegetation or sediment surface). There were few significant effects on any other taxa and these effects were also localised and short-lived. These results suggest that applications of Bti and $s$-methoprene do not impact the abundance and composition of non-target arthropod assemblages in subtropical saltmarshes, although more work on potential sub-lethal effects of the insecticides is needed.
\end{abstract}

KEY WORDS: Bacillus thuringiensis var. israelensis $\cdot$ Bti $\cdot s$-methoprene $\cdot$ Mosquito control · Saltmarsh · Ecological impacts · Australia · Copepoda · Acariformes

\section{INTRODUCTION}

In recent years, concern has arisen over the potential for an increase in mosquito-borne diseases as a consequence of global climatic change (Tanser et al. 2003, McMichael et al. 2006). There is now strong evidence that the world's average temperature is forecast to increase by a further 1.4 to $5.8^{\circ} \mathrm{C}$ by 2100 (IPCC 2007). Additionally, the global average rainfall and sea level are also forecast to increase over this time period (IPCC 2007). These projected changes have implications for human health around the globe due to changes in vector survival and pathogen development. The predicted increases in rainfall and temperature are likely to extend the home range of mosquitoes and associated pathogens, in addition to shortening the development time of mosquito larvae and the extrinsic incubation period of pathogens (Tanser et al. 2003, McMichael et al. 2006). In particular, warmer and wetter weather is likely to result in longer seasonal activity of mosquitoes and sea level rise will produce more areas of wetland habitat by 
gradually inundating coastal regions, providing more habitat suitable for use by mosquito larvae (Tanser et al. 2003).

The primary focus of mosquito control in many countries is reducing larval populations and often involves the integrated use of physical habitat modification and application of insecticides. Physical habitat modification (e.g. runnelling) involves digging channels through wetland areas, such as saltmarsh, to link isolated pools with the tidal source. This increases water movement during low amplitude tides and, consequently, larval development (Hulsman et al. 1989) and egg conditioning (Dale et al. 2002) of mosquitoes is unsuccessful. Even though physical habitat modification has been used extensively, the application of insecticides remains the most common approach in most parts of the world (Rose 2001, Russell \& Kay 2008).

The common insecticides used to control mosquitoes in saltmarsh and mangrove habitats are Bacillus thuringiensis var. israelensis de Barjac (Bti) and $s$ methoprene (Mian \& Mulla 1982, Russell \& Kay 2008). $B t i$ is a soil-dwelling bacterium and $s$-methoprene is an insect growth regulator. When the proteins of Bti are ingested by mosquito larvae, they are dissolved and activated by the alkaline $\mathrm{pH}$ and proteinases of the larval midgut, releasing endotoxins that bind to receptors on the epithelial midgut cells of larvae. This results in an osmotic imbalance of the cells and rapid larvae death (Gill et al. 1992). The insecticide $s$-methoprene is a hormone mimic and, unlike natural juvenile hormones, the synthetic analogue is not affected by the destructive enzymes of larval metabolism. The hormone mimic acts via ingestion or cuticle contact and interferes with neuroendocrine functions causing failure of pupae to emerge from cases (Mian \& Mulla 1982).

Despite the fact that Bti and s-methoprene are considered to be among the most target-specific of the insecticides used for mosquito control (Mulla et al. 1982, Barnes \& Chapman 1998), there are indications that non-target organisms may be impacted by these products in different ecosystems (e.g. lentic freshwater: Norland \& Mulla 1975, Hershey et al. 1998; lotic freshwater: Car \& de Moor 1984, Back et al. 1985). Many laboratory studies have provided information on the specific responses of different taxa to Bti and/or smethoprene, with the majority of these studies recording no impacts when non-target insects were exposed to operational concentrations (see reviews by Glare \& O'Callaghan 1998, Boisvert \& Boisvert 2000). However, laboratory-based trials may fail to predict the effects of insecticides in the field due to interactions with ecological factors that may alter their effects, such as predation and availability of food (Ward et al. 1976, Underwood 1995).
Only one study, Hershey et al. (1998), has investigated the long-term ecological impacts of Bti and $s$-methoprene under field conditions. The study was conducted in lentic freshwater systems in Minnesota, USA, and the results contradicted those from many laboratory-based toxicological experiments, showing that the abundance of freshwater insects was significantly reduced for $3 \mathrm{yr}$ after repeated applications of $B t i$ and $s$-methoprene. However, it may be inappropriate for managers to apply this information to saltmarsh systems. For example, the tropical and subtropical saltmarshes on the east coast of Australia are fundamentally different to lentic freshwater systems in the US in terms of hydrology (tidal versus rain flooded) and food web structure. Australian saltmarshes do, however, provide many important ecosystem services that require protection from the environmental consequences of insecticide treatments. These include high levels of primary production and inputs into coastal food webs, habitat for fishes (Thomas \& Connolly 2001) and birds, and a buffer zone between the land and the sea (Faulkner 2004). There is almost no information on the ecological impacts of Bti and s-methoprene applications in Australian saltmarshes, despite this being the primary means by which the transmission of pathogens from mosquitoes to humans has been controlled for over 10 yr (Russell \& Kay 2008).

In the present study we investigated whether the application of Bti and $s$-methoprene would affect the density and diversity of non-target arthropods in subtropical Australian saltmarshes. We examined the common arthropods that would be exposed to routine mosquito control operations, including both terrestrial and aquatic organisms. A trade-off exists between the human health imperative to prevent disease transmission and protection of the environment from unnecessary use of insecticides (Rose 2001). The results of the present study provide important information for mosquito control operators and environmental managers on the environmental consequences of the use of insecticides to control mosquitoes in wetlands.

\section{MATERIALS AND METHODS}

Study area. The study was done in 2 locations (Coomera Waters and Garden Island), in Moreton Bay, a large, subtropical, estuarine embayment in southeast Queensland, Australia (Fig. 1). The intertidal flats at each of the locations are characterized by 3 broad zones: a saltmarsh fringe along the upper shore (primarily Sarcocornia quinqueflora [Bunge ex Ung.Sternb.] and Sporobolus virginicus [L.] Kunth and interdispersed with saltpans), a mid-intertidal mangrove flat (primarily Avicennia marina var. australasica 
Fig. 1. Queensland, Australia, and the Moreton Bay region showing the locations used to examine the effects of Bti and $s$-methoprene on non-target arthropods in saltmarsh systems
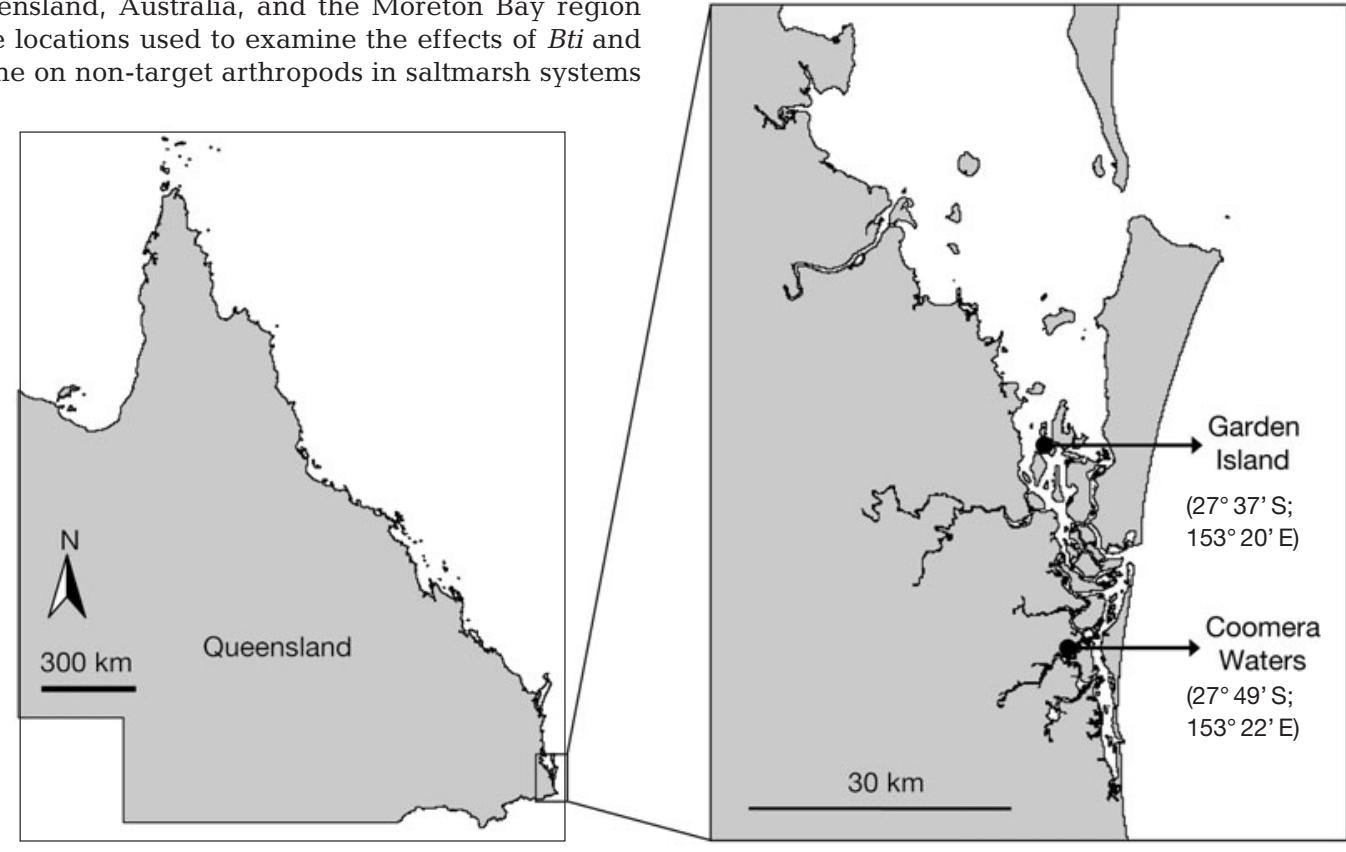

[Walp.]) and a lower-intertidal mudflat with intermittent sea grass beds (primarily Zostera capricorni Ascherson). All locations were typical of sites that would be targeted for mosquito control in southeast Queensland and were at least 0.5 ha in size and without grazing by hoofed animals. The locations had previously been treated for mosquito control, primarily with Bti, at a similar intensity each summer: ca. once per month at the manufacturer's recommended rate. The target mosquito species were the Ross River virus vectors Aedes vigilax (Skuse) and Culex sitiens Wiedemann. Due to the scale of routine mosquito control operations, we were unable to locate suitable sites that had not been previously treated with insecticides. At the time of the experiments, the locations had been free from insecticide use for $\geq 1$ mo (local government records; Contiguous Local Authorities Group 2005).

Tides at the locations are semidiurnal with a range of 0.8 to $2.0 \mathrm{~m}$ within a full monthly tidal cycle. The mudflat and mangroves are inundated on a daily basis by high tides, whereas the saltmarsh is inundated for up to 4 consecutive days during spring tides (flooded for an average of 4 to $5 \mathrm{~h}$ per high tide) but rarely on other occasions. On a yearly basis, about $7 \%$ of tides totally inundate the saltmarsh, although this varies across seasons, with more inundations during the day in the Austral summer and during the night in the Austral winter (Connolly 2005). As the water drains from the saltmarsh with the receding tide, water remains in depressions in the substratum, forming stagnant pools that persist for 1 to $7 \mathrm{~d}$.

Experimental design. During routine aerial control operations, the insecticides are applied as a 'blanket' to the saltmarsh; therefore, the effect of insecticide applications on both terrestrial and aquatic arthropods was examined. The general hypothesis tested was that applications of $B t i$ and/or s-methoprene would cause significant changes to the assemblages of non-target arthropods. Some groups of arthropods (e.g. chironomids) may be directly impacted by the application of insecticides, leading to a reduction in their abundance. Other groups may be indirectly affected, with possible increases or decreases in abundance mediated by a change in the abundance of prey, competitors or predators. No indirect effects of Bti and s-methoprene on non-target arthropods have been previously demonstrated, but this is not surprising considering the paucity of field trials that have been done.

To test the hypothesis, experimental applications of both Bti and $s$-methoprene were added to plots in the saltmarsh habitat and, over the subsequent 20 d, nontarget arthropods were sampled from both insecticidetreated and untreated control plots. The experimental plots (detailed below) were established along a visually uniform stretch of saltmarsh without natural barriers (e.g. creeks, etc.). Initially, a pilot experiment was done to develop appropriate methods for sampling terrestrial and aquatic invertebrates in the saltmarsh. This was necessary as there was little available information on the composition, abundance or spatial variability of terrestrial and aquatic arthropods in Moreton Bay saltmarshes and it was important to test the appropriateness of the sampling methods (Andrew \& Mapstone 1987).

Experimental application of insecticides: Experimental applications of $B t i$ and $s$-methoprene were done at 
2 widely separated $(\sim 30 \mathrm{~km})$ locations. Coomera Waters, on the western side of the bay, is an area dominated by urban, rural and industrial developments, whereas Garden Island, in the centre of the bay, is an undeveloped low-lying island. The quality of the environment varied considerably between these 2 localities, but we had no specific interest here in comparing developed to undeveloped areas, only to examine the generality of any effects from mosquito treatment on non-target saltmarsh fauna.

At each location, we conducted one experimental application of Bti and, during a second time period, an application of $s$-methoprene (Table 1 ). For each of the trials, plots were selected within the saltmarsh at each location: 8 terrestrial plots $(11 \times 3 \mathrm{~m}$; covered in strands of Sarcocornia quinqueflora and/or Sporobolus virginicus) and 8 ephemeral pools (variable area, see Table 1; 5 to $15 \mathrm{~cm}$ deep) (a total of 64 plots). The plots were permanently marked with $40 \mathrm{~cm}$ long wooden stakes, pushed into the substratum at the corners of terrestrial plots and at one end of each pool. Adjacent plots were separated by 80 to $120 \mathrm{~m}$. The plots that were selected for the 2 consecutive insecticide applications were separated from each other by a distance of $500 \mathrm{~m}$, so any effects from the first application would not have affected the plots used for the second application.

In each trial, 4 terrestrial and 4 aquatic plots were designated at random for insecticide treatment. The product, diluted with non-chlorinated tap water at a ratio of $1: 2$, was applied evenly to the surface of the treated plots at the recommended label rate, using a pressure-pump hand-held sprayer. The remaining 4 terrestrial and 4 aquatic plots served as untreated controls. The trials were done between December 2004 and March 2005 (Table 1). The insecticide was applied immediately after the spring high tide period when the saltmarshes are flooded, so the experimental plots were not tidally inundated during the course of the experiment (20 d). The application rate of the chemicals and timing of the trials within the monthly tidal cycle mimicked the mosquitocontrol operations that are regularly carried out by local governments in southeast Queensland.
Sampling methods: Analysis of the data from the pilot experiments indicated that there was a large amount of variation between replicate samples caused by sampling biases associated with the specific area of pools that was sampled, the deployment of the pit-fall traps and the aspirator (authors' unpubl. data). Sampling methods for the main experiments were therefore modified to reduce these biases.

The terrestrial plots were sampled with pit-fall traps (Chapman et al. 1998) and aspirators (Gratton \& Denno 2005) for non-target invertebrates at 1, 5, 8 and $20 \mathrm{~d}$ after the plots were treated. To reduce biases from repeated sampling in the same spot (Skilleter 1996), a different $2 \times 2 \mathrm{~m}$ subplot was sampled on each occasion.

Four pit-fall traps (each comprising 3 adjacent units with a total aperture of $99.5 \mathrm{~cm}^{2}$ and $8 \mathrm{~cm}$ deep) were dug into the ground, flush with the substrate, in the corner of each subplot (30 cm inside). Any gaps around the edges of the trap were packed with mud. The traps were opened for $24 \mathrm{~h}$ before being sampled, with a small amount (10 to $20 \mathrm{ml}$ ) of detergent and water (1:1 ratio) placed in the bottom. After samples were collected, the traps were removed from the substratum and the holes filled.

One sample of arthropods from the vegetation was taken from each subplot using a hand-held suction sampler (Black \& Decker, 3.6 V). The collection nozzle sampled an area of $0.001 \mathrm{~m}^{2}$ and was moved to evenly cover the area of the plot in $1 \mathrm{~min}$. Arthropods were trapped in a cotton bag placed inside the aspirator. The entire $2 \times 2 \mathrm{~m}$ subplot was sampled and one person gradually walked through each subplot while moving the aspirator to cover evenly the area of the subplot within $1 \mathrm{~min}$.

The ephemeral pools were sampled for non-target organisms using a sweep net $(20 \times 30 \mathrm{~cm}$ aperture, $250 \mu \mathrm{m}$ mesh) at 1 and $4 \mathrm{~d}$ post-insecticide application, but after this time there was insufficient water remaining in the pools for further sampling. To collect arthropods, sweeps of the net were made from the centre of

Table 1. Plot size (mean $\pm \mathrm{SD}$ ) and experimental treatments of Bti and s-methoprene in 2 saltmarsh locations in Moreton Bay to examine potential impacts on non-target terrestrial and aquatic arthropods. $n=4$ for each experimental factor (treated and control plots; i.e. total of 8 plots per experiment)

\begin{tabular}{|c|c|c|c|c|c|}
\hline \multirow[t]{3}{*}{ Active ingredient, formulation (rate) } & \multirow{3}{*}{$\begin{array}{l}\text { Treatment } \\
\text { date }\end{array}$} & \multirow[t]{3}{*}{ Location } & \multirow{3}{*}{ Terrestrial } & \multicolumn{2}{|c|}{ - Plot size $\left(\mathrm{m}^{2}\right)-$} \\
\hline & & & & $\mathrm{Aq}$ & \\
\hline & & & & Treatment & Control \\
\hline \multirow[t]{2}{*}{ Bti, VectoBac 12AS (1.2 $\left.1 \mathrm{ha}^{-1}\right)$} & 9 Feb 2005 & Coomera Waters & 33.0 & $144.9 \pm 149.0$ & $123.1 \pm 109.8$ \\
\hline & 16 Dec 2004 & Garden Island & 33.0 & $42.0 \pm 16.9$ & $93.4 \pm 76.4$ \\
\hline \multirow{2}{*}{$\begin{array}{l}s \text {-methoprene, Altosid Liquid Larvicide } \\
\left(0.36 \mathrm{l} \mathrm{ha}^{-1}\right)\end{array}$} & 13 Jan 2005 & Coomera Waters & 33.0 & $163.7 \pm 144.5$ & $104.3 \pm 106.5$ \\
\hline & 10 Mar 2005 & Garden Island & 33.0 & $72.3 \pm 57.2$ & $63.0 \pm 67.5$ \\
\hline
\end{tabular}


the pool towards the outside, in an area of approximately $1 \mathrm{~m}^{2}$, for $1 \mathrm{~min}$. Two samples, separated by the maximum distance possible, were collected from each pool. All samples were washed across a $250 \mu \mathrm{m}$ sieve to remove sediment and debris and the contents were then preserved in $7 \%$ formalin containing the stain Rose Bengal.

All animals from the terrestrial samples were removed, counted and identified. Due to large numbers of animals in the aquatic samples, a 10\% subsample was sorted. The entire sample was placed in $500 \mathrm{ml}$ of water and stirred with a magnetic stirrer to create a homogenous solution, then $50 \mathrm{ml}$ was extracted, from which all individuals (except mosquito larvae) were removed, counted and identified. Identification of organisms to the level of species is frequently unnecessary for the detection of environmental impacts in habitats such as mangroves and saltmarshes (e.g. Chapman 1998), so taxonomic analysis was performed to the level of order or subclass.

Statistical analyses. Initially, the effect of Bti and $s$-methoprene application on the composition and/or relative abundances of different taxa was examined using multivariate analyses. Data on the abundance of non-target invertebrates collected after each experimental application (Table 1) for each sampling technique $(\mathrm{n}=3)$ were analysed separately. Differences in the community composition between insecticide-treated and untreated plots were examined using permutational multivariate ANOVA (PERMANOVA; Anderson 2001), with terms Treatment (fixed: treated versus control), Time (fixed: terrestrial $=4$ levels, aquatic $=2$ levels) and Plot (nested within Treatment $\times$ Time, 4 levels). The differences were examined graphically using non-metric multidimensional scaling (nMDS) in PRIMER (Clarke 1993). The PERMANOVA and nMDS analyses were based on the Bray-Curtis similarity measure and 4th-root transformed data. The 4th-root transformation was used because samples were dominated by a few very abundant taxa (e.g. copepods) and this transformation places greater emphasis on the rare species (Clarke 1993).

Differences in the abundance of individual taxa that contributed $>10 \%$ to the community composition (determined using SIMPER analysis; Clarke 1993) were analysed using 2-way univariate ANOVAs with the same design as the multivariate analyses. Data were $\log _{\mathrm{e}}$-transformed to meet the assumptions of heteroscedasticity of variances after Cochran's test (Underwood 1997). In all cases, transformation removed heteroscedasticity of variances. When appropriate, post hoc pooling of mean square estimates (Underwood 1997) was used to determine significant differences in each factor.

\section{RESULTS}

\section{Effects of Bti and s-methoprene on community composition}

The effects of Bti and s-methoprene on the community composition of terrestrial and aquatic habitats were extremely variable from place to place, but were generally short-term (Table A1 in Appendix 1). At Coomera Waters, there was a significant effect of Bti on terrestrial and aquatic communities, both as a main effect (PERMANOVA, aspirator: $F_{1,31}=3.79, \mathrm{p}=0.003$ ) or as an interaction with time (pit-fall: $F_{3,127}=2.04, \mathrm{p}=$ 0.018; sweep net: $F_{1,23}=9.47, \mathrm{p}<0.001$ ) (Fig. A1). For the pit-fall samples, there was a difference between treated and control plots after $5 \mathrm{~d}$ (a posteriori, $\mathrm{p}=$ 0.047 ), but this was no longer present after $8 \mathrm{~d}$. The aquatic community sampled with the sweep net was significantly different between treated and control pools after $1 \mathrm{~d}$ (a posteriori, $\mathrm{p}=0.005$ ), but there was no effect of Bti after that. At Garden Island, there was no effect of Bti on the community in the vegetation (aspirator: $F_{1,31}=0.08, \mathrm{p}=0.963$ ) or sediment surface (pitfall: $\left.F_{1,127}=0.53, \mathrm{p}=0.695\right)$. There was, however, a significant effect on the aquatic community which was consistent over the course of the experiment (sweep net, main effect: $F_{1,23}=3.25, \mathrm{p}=0.030$ ) (Fig. A1).

In contrast, there was no effect of $s$-methoprene on the community in the vegetation at Coomera Waters (PERMANOVA, aspirator: $F_{1,31}=1.33, \mathrm{p}=0.224$ ), but there were significant impacts, consistent over the course of the experiment, on the community on the sediment surface (pit-fall, $F_{1,127}=3.41 \mathrm{p}=0.015$ ) and in the pools (sweep net: $F_{1,23}=6.97, \mathrm{p}=0.002$ ) (Fig. A1). At Garden Island, there was no effect of $s$-methoprene on the community in the vegetation (aspirator: $F_{1,31}=$ $0.50, p=0.729$ ) and the impacts on the sediment surface and aquatic communities were an interaction with time (pit-fall, interaction: $F_{3,127}=2.07, \mathrm{p}=0.031$; sweep net, interaction: $F_{1,23}=6.52, \mathrm{p}=0.005$ ) (Fig. A1); there was no a posteriori significance. There was generally poor separation of the communities in the treatment and control plots in ordination plots (Fig. A1), even when significant differences were detected with PERMANOVA.

\section{Effects on abundance of taxa}

A total of 15 different invetebrate taxa (2 classes of arachnids, 4 classes of crustaceans, 9 classes of insects and 1 class of nematodes) and 1869734 individuals were collected and identified from the main experiment. There were, however, very few significant effects of the insecticides on the abundance of these 
different groups (Table A2). Where there were significant effects associated with the treatment, they were usually as a Treatment $\times$ Time interaction, and any differences between treated and control plots were only detected for a short-time and often with large confidence intervals. More often though, there were significant changes in the abundance of different taxa through time, but the numbers in the treated and control plots tracked each other closely or the effect was not consistent for that taxon sampled with different methods.

As an example, mites (Acariformes, primarily Family Oribatulidae) were abundant in aspirator and pit-fall samples at both Coomera Waters and Garden Island. The abundance of mites in the vegetation (aspirator samples) was not significantly affected by $B t i$ at Coomera Waters (ANOVA, main effect: $F_{1,17}=0.528$, $\mathrm{p}=0.477$; interaction: $F_{3,17}=0.628, \mathrm{p}=0.606$ ), but was significantly enhanced by $B t i$ on the sediment surface (pit-fall samples) on Day 8 (main effect: $F_{1,104}=15.99$, $\mathrm{p}<0.001$; interaction: $F_{3,104}=3.352, \mathrm{p}<0.021$; Tukey's HSD, $p=0.002$ ) (Fig. 2A,B). By Day 20, numbers on the sediment surface were similar in the Bti-treated and control plots (Tukey's HSD, $\mathrm{p}=0.965$ ). In contrast, the abundance of mites in the vegetation (aspirator samples) was significantly enhanced by $s$-methoprene at Coomera Waters (main effect: $F_{1,19}=6.11, \mathrm{p}=0.023$ ), but there was no effect of $s$-methoprene on mites on the sediment surface (pit-fall, main effect: $F_{1,77}=1.30$, $\mathrm{p}=0.257$; interaction: $F_{3,77}=1.22, \mathrm{p}=0.307$ ) (Fig. $\left.2 \mathrm{C}, \mathrm{D}\right)$.

\section{Bti; Coomera Waters}
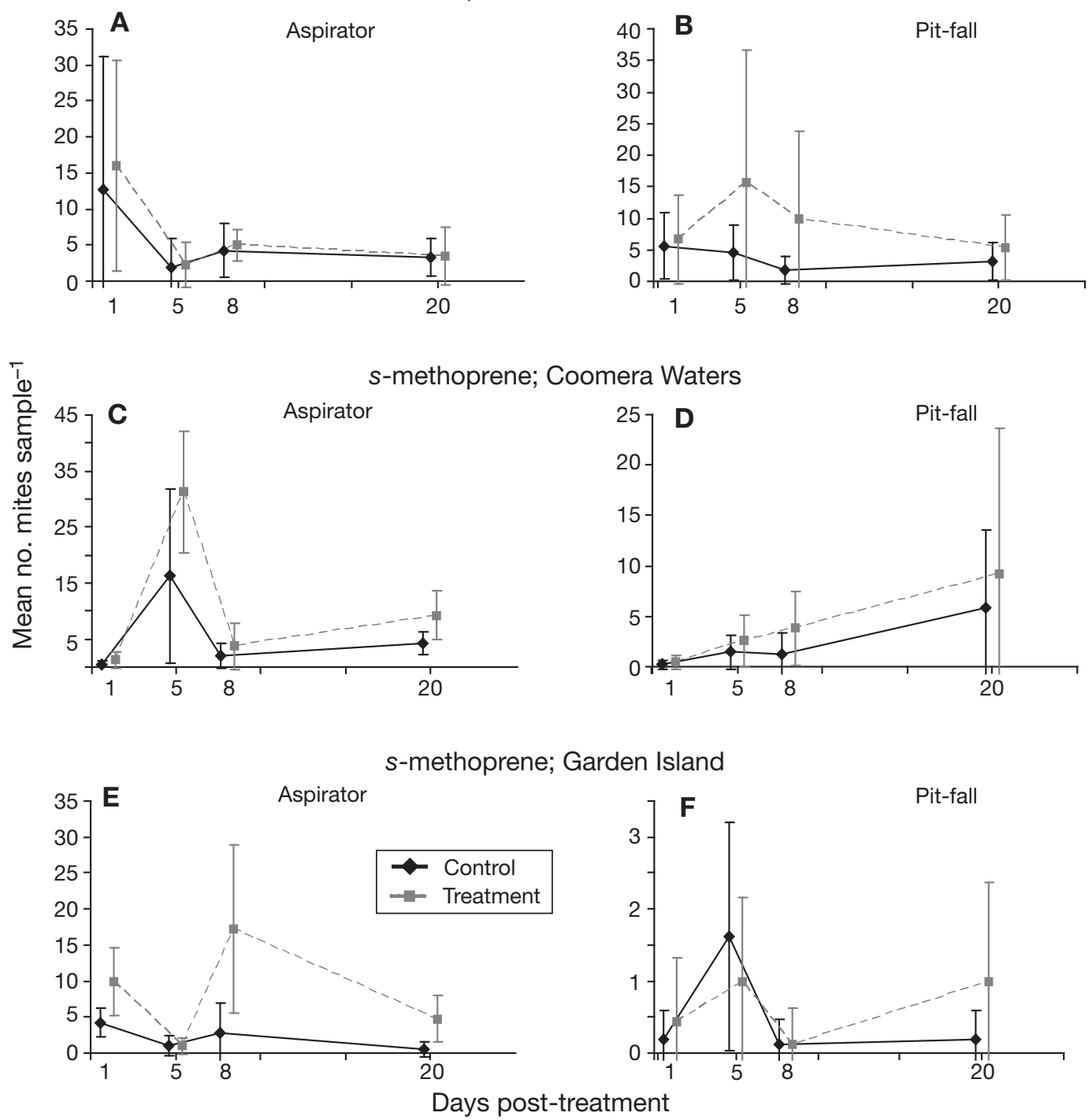

Fig. 2. Mean $( \pm 95 \% \mathrm{CL}$ ) number of mites (Acariformes) in treated and control plots sampled with either an aspirator $(\mathrm{A}, \mathrm{C}, \mathrm{E})$ or pit-fall traps $(\mathrm{B}, \mathrm{D}, \mathrm{F})$. Treated plots were exposed to either Bti $(\mathrm{A}, \mathrm{B})$ or $s$-methoprene $(\mathrm{C}-\mathrm{F})$ at Coomera Waters $(\mathrm{A}-\mathrm{D})$ and $\mathrm{Garden}$ Island $(\mathrm{E}, \mathrm{F})(\mathrm{n}=4$ samples for each mean). Note the different $y$-axis scales 


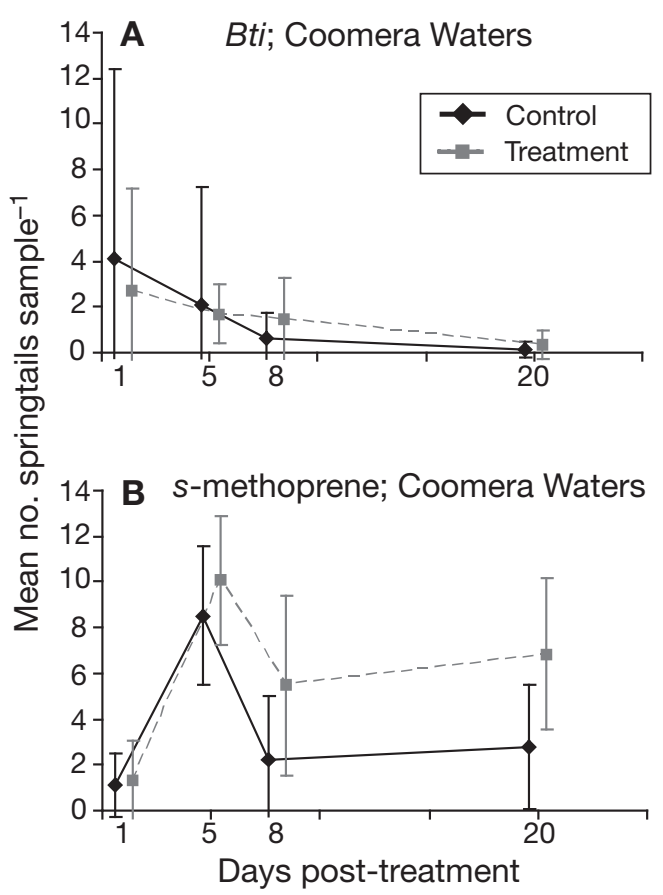

The effects of $s$-methoprene on mites in the vegetation and on the sediments at Garden Island were similar to those at Coomera Waters: significant enhancement in the vegetation (main effect: $F_{1,15}=0.84, \mathrm{p}=0.007$ ), but no effect on the mites on the sediment surface (main effect: $F_{1,34}=3.29, \mathrm{p}=0.077$, interaction: $F_{3,34}=2.39$, $\mathrm{p}=0.086$ ), although there was a suggestion of some enhancement at $20 \mathrm{~d}$ (Fig. 2E,F).

Another group that was abundant on the sediment surface (pit-fall samples) at both localities was the springtails, primarily Hypogastura vernalis (Carl) (Hypogasturidae, Collembola). There was no significant effect of $\mathrm{Bti}$ on the abundance of springtails at Coomera Waters (ANOVA, main effect: $F_{1,54}=0.08, \mathrm{p}=$ 0.776; interaction: $F_{3,54}=1.15, \mathrm{p}=0.336$ ) (Fig. 3A). In contrast, $s$-methoprene had a significant effect on the abundance of springtails at both Coomera Waters (main effect: $F_{1,89}=5.00, \mathrm{p}=0.028$ ) and Garden Island (main effect: $F_{1,53}=4.96, \mathrm{p}=0.030$ ), but these effects were opposite at the 2 localities, with increased numbers at Coomera Waters and decreased numbers at Garden Island relative to control plots (Fig. 3B,C).

Finally, the ephemeral pools were dominated by copepods, but numbers were extremely variable, ranging from 6 to 6150 individuals per pool. Many of the pools had dried before the $8 \mathrm{~d}$ samples could be collected, so only data for 1 to 4 d post-treatment were analysed and are presented. There was a significant effect of Bti on the number of copepods at Garden Island (ANOVA, main effect: $F_{1,28}=10.832, \mathrm{p}=0.003$ ) and as an interaction with time at Coomera Waters (main effect: $F_{1,24}=0.016, \mathrm{p}=0.901$; interaction: $F_{1,24}=$

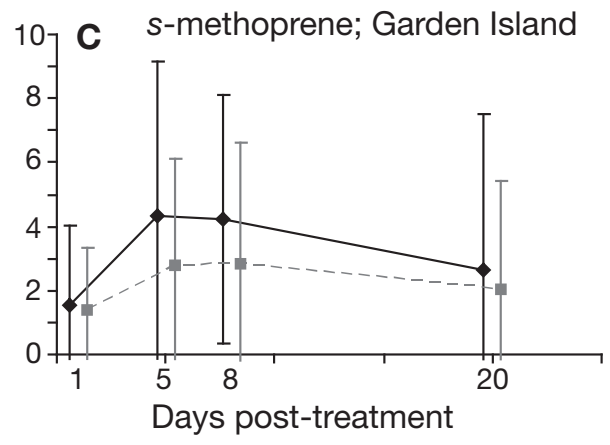

Fig. 3. Mean $( \pm 95 \% \mathrm{CL}$ ) abundance of springtails (Collembola) in treated and control plots sampled using pit-fall traps. Treated plots were exposed to either Bti (A) or s-methoprene $(\mathrm{B}, \mathrm{C})$ at Coomera Waters $(\mathrm{A}, \mathrm{B})$ and Garden Island $(\mathrm{C})(\mathrm{n}=4$ samples for each mean). Note the different $y$-axis scale in (C)

6.049, $\mathrm{p}=0$ 0.021) (Fig. 4A,B). At Garden Island there was a significant decrease in the abundance of copepods after $4 \mathrm{~d}$ (Tukey's HSD, $\mathrm{p}=0.011$ ), but there was no a posteriori significance. Regarding s-methoprene, there was no effect of treatment on copepods at Coomera Waters (main effect: $F_{1,26}=3.712, \mathrm{p}=0.065$; interaction: $\left.F_{1,26}=1.191, \mathrm{p}=0.285\right)$ and the effect at Garden Island was as an interaction with time (interaction: $F_{1,28}=4.962, \mathrm{p}=0.034$ ) (Fig. 4C,D).

The other groups that contributed to the overall separation of the community composition between insecticide treated and control plots were the dipterans (excluding mosquitoes), heteropterans (true bugs) and hymenopterans (primarily ants), but there were no significant effects of Bti or s-methoprene on the abundance of any of these groups, either as a main effect or as interaction with time. Numbers of individuals in these groups were often very small and the differences between treated and control plots were small relative to the magnitude of fluctuations through time; sometimes treated plots contained more individuals than the controls, but at other times the opposite was true. As an example, hymenopterans were abundant at Coomera Waters (Fig. 5A,C) and were less abundant at Garden Island (Fig. 5B,D), but there was no effect of Bti or $s$ methoprene on the abundance of hymenopterans at either locality. Numbers in treatment and control plots showed similar temporal fluctuations at Garden Island. Fluctuations in numbers in treatment and control plots at Coomera Water were less synchronous but there was still no indication of a significant effect of the insecticides. 


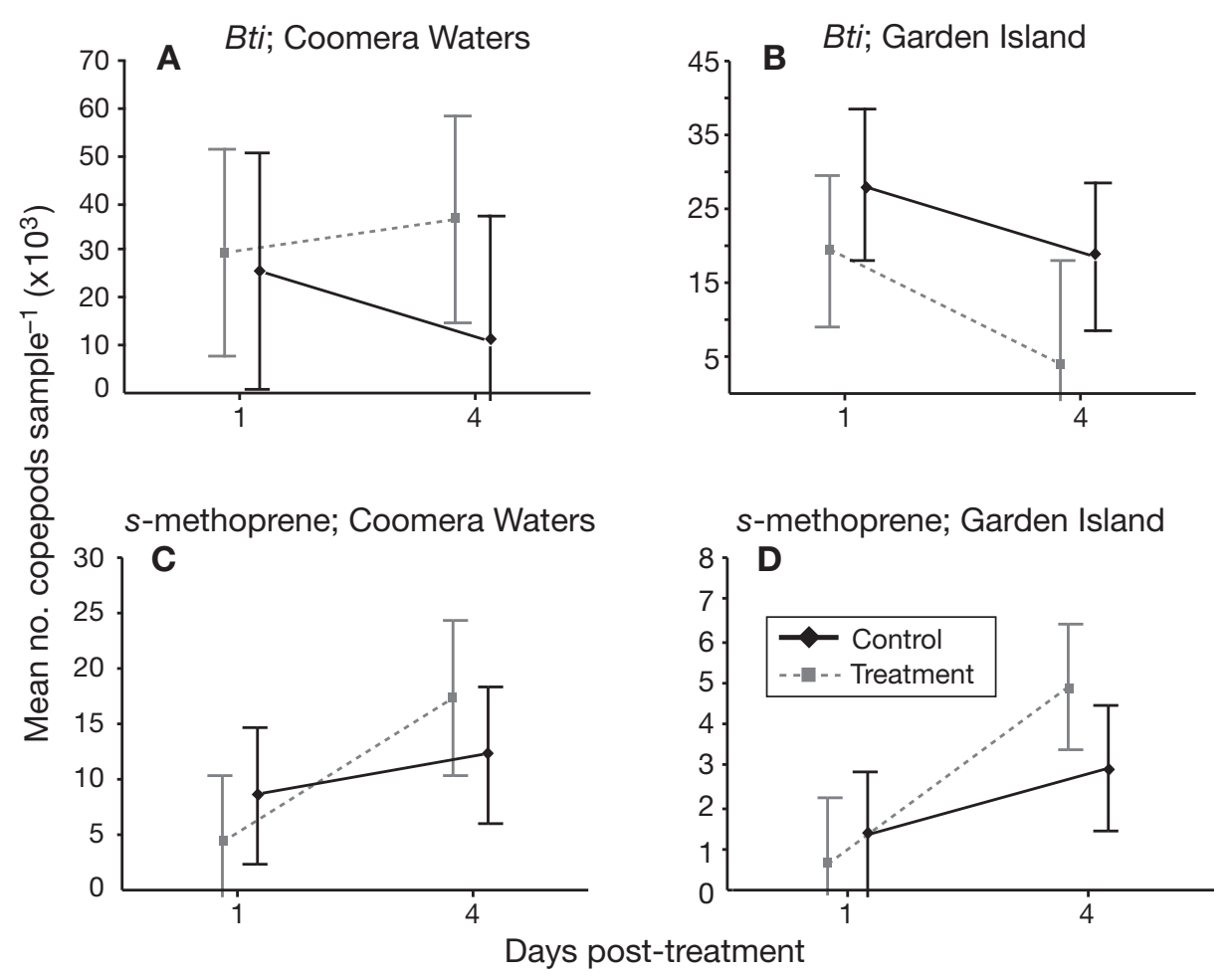

Fig. 4. Mean $( \pm 95 \% \mathrm{CL})$ abundance of copepods in treated and control plots sampled using sweep nets in ephemeral pools. Treated plots were exposed to either Bti $(\mathrm{A}, \mathrm{B})$ or $s$-methoprene $(\mathrm{C}, \mathrm{D})$ at Coomera Waters $(\mathrm{A}, \mathrm{C})$ and Garden Island $(\mathrm{B}, \mathrm{D})(\mathrm{n}=4$ samples for each mean). Note the different $y$-axis scales

\section{DISCUSSION}

The design of these experiments mimicked mosquito control operations conducted in southeast Queensland and therefore provided a realistic indication of whether such operations cause impacts on non-target arthropods in subtropical saltmarshes. Generally, the results indicate that applications of Bti and s-methoprene do not lead to a decrease in diversity or in the total abundance of arthropods in these saltmarsh environments. Some effects of one or the other of the insecticides on the abundance of mites (Acariformes), springtails (Collembola) and copepods were recorded, but these effects were either short-term or inconsistent between localities and/or depended on which sampling method was used. There were also significant effects on community composition but, again, these were short-lived. Temporal fluctuations in numbers of all arthropod taxa were generally much greater in magnitude than any differences between treatments.

There was some evidence for short-term effects on the numbers of mites (Family Oribatulidae), with both $B t i$ and $s$-methoprene contributing to an increase in numbers on sediments and vegetation, although the specific effects varied between the 2 localities. Members of this family are mostly secondary decomposers, feeding predominantly on detritus material, microor- ganisms and fungi (Walter \& Proctor 1999), although there is increasing evidence that some species of oribatids are predatory or necrophagous (Schneider et al. 2004). Numbers of predatory or scavenging mites may increase in response to the presence of increased numbers of prey or dead/moribund animals, but there was no consistent evidence of impacts on other taxa. Springtails (Collembolans) have been found to be the preferred prey of some predatory mites (Peschel et al. 2006), but there was no effect of Bti on the number of springtails and $s$-methoprene was related to an increase in their abundance at one locality but a decrease at the other. Whatever the mechanism behind the effects of the insecticides on the numbers of mites, these effects had disappeared after $8 \mathrm{~d}$.

The duration of the present study was selected after considering the persistence of the insecticides in the environment. Regarding Bti, there are few tests available to measure persistence, which is most commonly measured by exposing target animals. As such, persistence studies are based on the availability of toxic spores to target animals and not necessarily the fact that the spores have degraded into non-toxic entities. The majority of persistence studies have recorded a short period of activity to mosquitoes of less than $7 \mathrm{~d}$ (Russell \& Kay 2008). However, interactions with sediments and vegetation may render the Bti crystals 


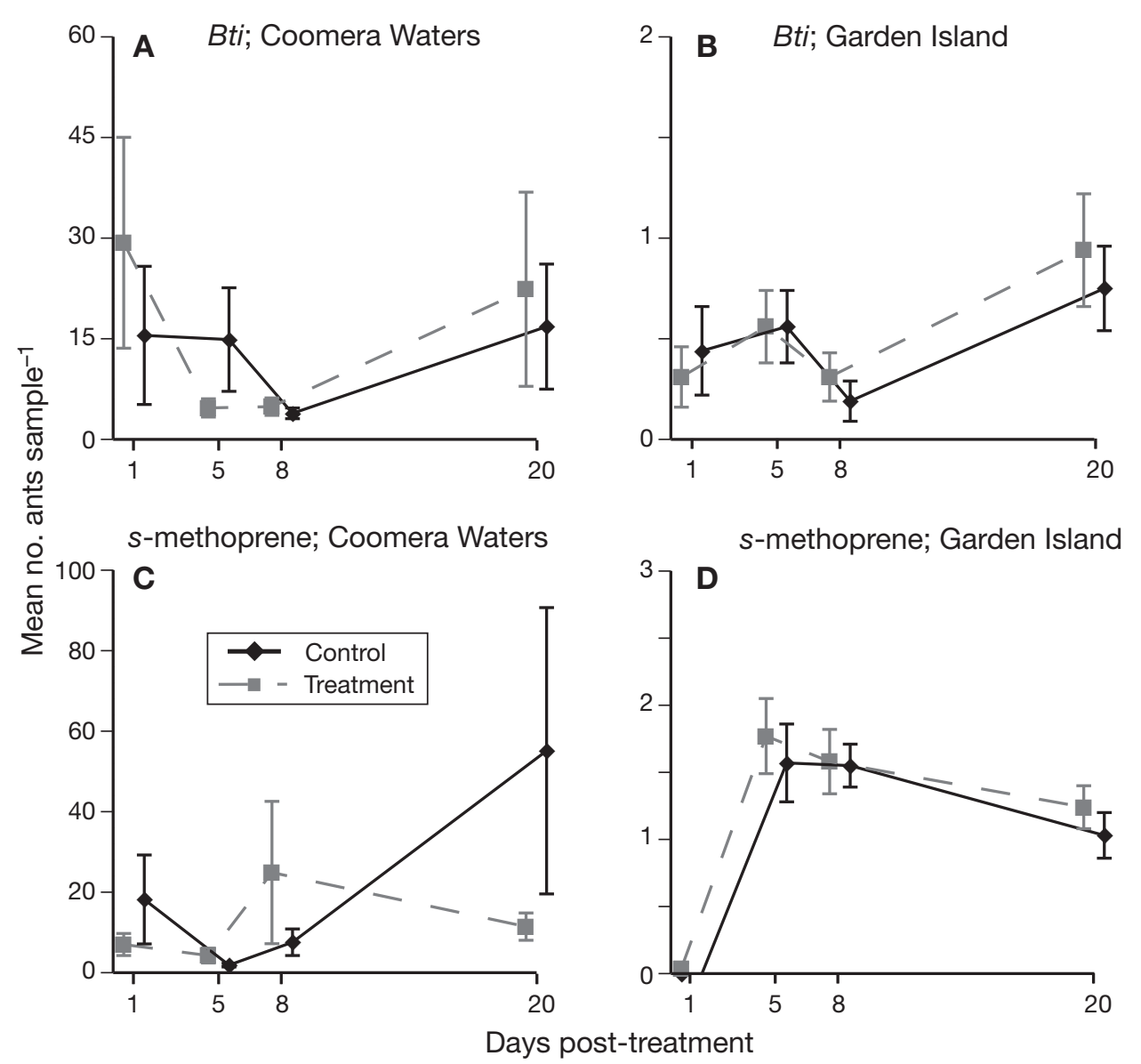

Fig. 5. Mean $( \pm 95 \% \mathrm{CL})$ abundance of ants (Hymenoptera) in treated and control plots sampled using pit-fall traps. Treated plots were exposed to either Bti $(A, B)$ or $s$-methoprene $(C, D)$ at Coomera Waters $(A, C)$ and Garden Island $(B ; D)(n=4$ samples for each mean). Note the different $y$-axis scales

unavailable to filter feeding mosquitoes, while they may still be toxic to animals with other feeding mechanisms; s-methoprene also degrades rapidly in sunlight, both in water and on sediments. The presence of $s$-methoprene can be detected by gas-liquid chromatography and enzyme-linked immunosorbent assay (ELISA), but most accurately by exposing target mosquitoes, which are sensitive at concentrations as low as $5 \mathrm{ppb}$ (Glare \& O'Callaghan 1998). The persistence of $s$-methoprene can be extended by changes in formulation; however, the liquid formulation used in the present study only persists for 7 to $10 \mathrm{~d}$ (Russell \& Kay 2008). The short-term effects on non-target invertebrates recorded during the present study are consistent with the short activity of the products against target organisms.

The field experiments described here examined acute effects of Bti and s-methoprene on saltmarsh arthropods. Laboratory studies have shown that there are a number of chronic (non-lethal) effects of $s$ methoprene on non-target organisms that undergo similar moult cycles to mosquitoes, including weight loss and delayed release of broods in estuarine mysids (Horst \& Walker 1999), altered shell formation in blue crab (Templeton \& Laufer 1983) and reduced growth and altered reproduction of branchiopods (Olmstead \& LeBlanc 2001, 2003). If such chronic effects of s-methoprene occur in the field and eventually translate into changes in abundance of specific taxa (Ward et al. 1976, Underwood 1995), it is likely that periods longer than $20 \mathrm{~d}$ may be required for such changes to be observed. Further work in the field is warranted given the compelling indications of sublethal impacts in laboratory studies.

Studies from the northern hemisphere have suggested that $s$-methoprene is more broadly toxic to nontarget organisms than Bti. These northern hemisphere studies suggest strong effects of Bti on midges (Chironomidae; Hershey et al. 1995, Hershey et al. 1998, Rey et al. 1998, Niemi et al. 1999), with minimal impact on other insects (Boisvert \& Boisvert 2000). In contrast, high dosages of $s$-methoprene have been suggested to impact on a range of dipterans including chironomids (Ali 1991, Hershey et al. 1998), but also other insects 
such as mayflies (Ephemeroptera; Barnes \& Chapman 1998). Insufficient numbers of Chironomidae and Ephemeroptera were collected during the present study to examine the relative effects of Bti and $s$ methoprene application. However, there was no evidence of greater toxicity of $s$-methoprene than Bti on saltmarsh arthropods in the present study. The results of the present study are consistent with those of Barnes \& Chapman (1998), who did not find any effect of Bti on the abundance of insect larvae (chironomids), crustaceans or molluscs in temperate saltmarshes in New South Wales. Their study used a before/after design, but focused on benthic organisms collected in sediment samples. Their results and ours suggest that Bti may have very limited acute impacts on Australian saltmarsh fauna.

The areas that were used for these experiments are subjected to regular (seasonal) spraying with insecticides for the treatment of mosquitoes, so it is possible that the long-term use of Bti and/or s-methoprene had already significantly impacted on the fauna in these saltmarshes. The experiments described here may, in effect, represent part of a longer-term press perturbation (Underwood 1989) on saltmarsh arthropods, or form part of a disturbance-recovery cycle from regular pulse disturbances (Johnston \& Keough 2002). Some studies suggest that animals already affected by longer term stresses may be more susceptible to the effects of pulse disturbances. For example, bivalves in estuarine soft sediments in Western Australia were more susceptible to smothering from sediments when they were stressed from increased competition for food at greater densities (Peterson \& Black 1988), and crayfish were more susceptible to floods (pulse disturbances) when they were already stressed from land-use changes (press disturbances; Parkyn \& Collier 2004). Alternatively, long-term exposure to mosquito insecticides may result in only the more resilient, or perhaps more tolerant, species remaining in local saltmarshes. This may account for the relatively few significant impacts of these insecticides that were detected in the present study, compared with those found by Hershey et al. (1998), who worked in wetlands not previously treated with mosquito insecticides. Differences in the nature of the disturbance (i.e. press versus pulse) are likely to result in different types of responses in populations and communities over different time periods (Bender et al. 1984, Johnston \& Keough 2002), but clearly more work is needed to understand the implications of press versus pulse applications of insecticides on aquatic fauna.

$B t i$ and $s$-methoprene are the main insecticides that are used for mosquito control operations in Australia and over 1 tonne of each product is applied to wetlands in Australia per year (Russell \& Kay 2008). Both these products appear safer than the organophosphate alternatives. The organophosphates registered for mosquito control are broad spectrum insecticides and are toxic to a range of arthropods, including insects (Hurlbert et al. 1970, Didia et al. 1975) and crustaceans (Didia et al. 1975, Mortimer \& Chapman 1995, Key et al. 1998). The use of organophosphate-based insecticides for agriculture is well documented to cause severe environmental impacts, including toxicity to non-target organisms (Barron \& Woodburn 1995).

Mosquito control operations in Australia currently incorporate the use of insecticides in conjunction with physical habitat modification. The use of either control option should be included on a case-by-case basis, after the efficacy and environmental impacts of each option are considered. Runnelling increases the transportation of mangrove propagules into the saltmarsh (Breitfuss 2003) and affects the abundance of gastropods, crabs, prawns and fish through a lowering of the tidal flooding regime for an area, but these changes are isolated to within $10 \mathrm{~m}$ of runnels (Breitfuss et al. 2004, Connolly 2005). Runnelling appears though to have minimal long-term impacts over the broader area of saltmarshes (Jones et al. 2004).

The results of the present study suggest that application of either Bti or $s$-methoprene is one of the more environmentally sound methods of mosquito control currently available. Application of either product did not lead to a decrease in the diversity or abundance of a wide range of non-target arthropods, at least over the short-term. However, more work is needed to determine if there are chronic (non-lethal) impacts that may lead to longer-term effects on saltmarsh communities. The saltmarshes in southeast Queensland are being increasingly exposed to intense and more diverse combinations of human disturbance (Faulkner 2004). Efficient management of the ecological and economic qualities of these habitats depends on the identification of the types and levels of disturbances that cause damage and those that do not. With such knowledge, informed decisions can be made about which disturbances must be removed and which, in fact, do not cause any significant impacts and can be tolerated. The results of the present study suggest that applications of Bti and s-methoprene will not impact the structure and composition of arthropod assemblages in saltmarshes. This information is essential for developing the most environmentally sound mosquito control operations possible.

Acknowledgements. Thanks go to Gold Coast City, Redlands Shire and Pine Rivers Shire Councils for support and the provision of field sites. Many thanks to J. A. L. Jeffery, T. P. Hurst, A. Guerney (QIMR) and particularly S. A. Lyons (QIMR) and N. Aurisch (UQ), who spent many hours in the field, assisting 
with the collection of samples. This work was primarily funded by an Australian Postgraduate Award to T.L.R and was conducted under a Queensland Parks and Wildlife Service Marine Park Permit (QS2004/CVL887). The manuscript was improved by constructive comments from M. G. Chapman and 4 anonymous reviewers.

\section{LITERATURE CITED}

Ali A (1991) Activity of new formulations of methoprene against midges (Diptera: Chironomidae) in experimental ponds. J Am Mosq Control Assoc 7:616-620

Anderson MJ (2001) A new method for non-parametric multivariate analysis of variance. Austral Ecol 26:32-46

Andrew NL, Mapstone BD (1987) Sampling and the description of spatial pattern in marine ecology. Oceanogr Mar Biol Annu Rev 25:39-90

Back C, Boisvert J, Lacoursiere JO, Charpentier G (1985) High-dosage treatment of a Quebec (Canada) stream with Bacillus thuringiensis serovar israelensis: efficacy against black fly larvae (Diptera: Simuliidae) and impact on nontarget insects. Can Entomol 117:1523-1534

Barnes PB, Chapman MG (1998) Effects of the larvicide (Vectobac) on assemblages of benthic invertebrates in Bicentennial Park. Centre for Research on Ecological Impacts of Coastal Cities, Sydney

Barron MG, Woodburn KB (1995) Ecotoxicology of chlorpyrifos. Rev Environ Contam Toxicol 144:1-93

$>$ Bender EA, Case TJ, Gilpin ME (1984) Perturbation experiments in community ecology: theory and practice. Ecology 65:1-13

Boisvert M, Boisvert J (2000) Effects of Bacillus thuringiensis var. israelensis on target and nontarget organisms: a review of laboratory and field experiments. Biocontrol Sci Technol 10:517-561

Breitfuss MJ (2003) The effects of physical habitat modification for mosquito control, runnelling, on selected nontarget saltmarsh resources. PhD dissertation, Griffith University, Nathan, Queensland

Breitfuss MJ, Connolly RM, Dale PER (2004) Densities and aperture sizes of burrows of Helograpsus haswellianus (Decapoda: Varunidae) on saltmarshes with and without mosquito control runnels. Wetlands 24:14-22

$>$ Car M, de Moor FC (1984) The response of Vaal River drift and benthos to Simulium (Diptera: Nematocera) control using Bacillus thuringiensis var. israelensis (H-14). Onderstepoort J Vet Res 51:155-160

Chapman MG (1998) Relationships between spatial patterns of benthic assemblages in a mangrove forest using different levels of taxonomic resolution. Mar Ecol Prog Ser 162:71-78

Chapman HF, Dale PER, Kay BH (1998) A method for assessing the effects of runneling on salt marsh grapsid crab populations. J Am Mosq Control Assoc 14:61-68

Clarke KR (1993) Non-parametric multivariate analysis of changes in community structure. Aust J Ecol 18:117-143

> Connolly RM (2005) Modification of saltmarsh for mosquito control in Australia alters habitat use by nekton. Wetlands Ecol Manage 13:149-161

Contiguous Local Authorities Group (2005) Contiguous Local Authorities Group (CLAG), Regional Mosquito Control Committee, Quarterly Reports 2004-2005. Gold Coast City Council, Queensland

- Dale PER, Chapman H, Brown MD, Ritchie SA, Knight J, Kay BH (2002) Does habitat modification affect oviposition by the salt marsh mosquito, Ochlerotatus vigilax (Skuse) (Diptera: Culicidae)? Aust J Entomol 41:49-54
Didia V, LaSalle R, Liem K (1975) The effects of Abate 2G mosquito larvicide on selected non-target organisms collected from forested temporary pools. Mosq News 35: $227-228$

Faulkner S (2004) Urbanization impacts on the structure and function of forested wetlands. Urban Ecosyst 7:89-106

$>$ Gill SS, Cowles EA, Pietrantonio PV (1992) The mode of action of Bacillus thuringiensis endotoxins. Annu Rev Entomol 37:615-636

Glare T, O'Callaghan M (1998) Report for the Ministry of Health: environmental and health impacts of the insect juvenile hormone analogue, $S$-methoprene. Biocontrol and Biodiversity, Grasslands Division, AgResearch, Lincoln

> Gratton C, Denno RF (2005) Restoration of arthropod assemblages in a Spartina salt marsh following removal of the invasive plant Phragmites australis. Restor Ecol 13:358-372

Hershey AE, Shannon L, Axler R, Ernst C, Mickelson P (1995) Effects of methoprene and Bti (Bacillus thuringiensis var. israelensis) on non-target insects. Hydrobiologia 308: $219-227$

- Hershey AE, Lima AR, Niemi GJ, Regal RR (1998) Effects of Bacillus thuringiensis israelensis (Bti) and methoprene on nontarget macroinvertebrates in Minnesota wetlands. Ecol Appl 8:41-60

$>$ Horst MN, Walker AN (1999) Effects of the pesticide methoprene on morphogenesis and shell formation in the blue crab Callinectes sapidus. J Crustac Biol 19:699-707

> Hulsman K, Dale PER, Kay BH (1989) The runnelling method of habitat modification: an environment-focused tool for salt marsh mosquito management. J Am Mosq Control Assoc 5:226-234

> Hurlbert SH, Keith JO, Westlake WE, Dusch ME (1970) Biological effects of persistence of Dursban in freshwater ponds. J Econ Entomol 63:43-52

IPCC (Intergovernmental Panel on Climate Change) (2007) Climate Change 2007. The Physical Science Basis. Contribution of Working Group 1 to the Fourth Assessment Report of the Intergovernmental Panel on Climate Change. Cambridge University Press, Cambridge

Johnston EL, Keough MJ (2002) Direct and indirect effects of repeated pollution events on marine hard-substrate assemblages. Ecol Appl 12:1212-1228

Jones J, Dale PER, Chandica AL, Breitfuss MJ (2004) Changes in the distribution of the grey mangrove Avicennia marina (Forsk.) using large scale aerial colour infrared photographs: Are the changes related to habitat modification for mosquito control? Estuar Coast Shelf Sci 61:45-54

- Key PB, Fulton MH, Scott GI, Layman SL, Wirth EF (1998) Lethal and sublethal effects of malathion on three life stages of grass shrimp, Palaemonetes pugio. Aquat Toxicol 40:311-322

> McMichael AJ, Woodruff RE, Hales S (2006) Climate change and human health: present and future risks. Lancet 367 : 859-869

> Mian LS, Mulla MS (1982) Biological and environmental dynamics of insect growth regulators (IGRs) as used against Diptera of public health importance. Residue Rev 84:27-112

Mortimer MR, Chapman HF (1995) Acute toxic effects of (s)methoprene and temephos to some Australian non-target aquatic crustacean species. Aust J Ecotoxicol 1:107-111

Mulla MS, Federici BA, Darwazeh HA (1982) Larvicidal efficacy of Bacillus thuringiensis serotype $\mathrm{H}-14$ against stagnant-water mosquitoes and its effects on nontarget organisms. Environ Entomol 11:788-795

> Niemi GJ, Hershey AE, Shannon L, Hanowski JM, Lima A, Axler RP, Regal RR (1999) Ecological effects of mosquito 
control on zooplankton, insects, and birds. Environ Toxicol Chem 18:549-559

Norland RL, Mulla MS (1975) Impact of altosid on selected members of an aquatic ecosystem. Environ Entomol 4: $145-152$

Olmstead AW, LeBlanc GL (2001) Low exposure concentration effects of methoprene on endocrine-regulated processes in the crustacean Daphnia magna. Toxicol Sci 62: $268-273$

Olmstead AW, LeBlanc GA (2003) Insecticidal juvenile hormone analogs stimulate the production of male offspring in the crustacean Daphnia magna. Environ Health Perspect 111:919-924

Parkyn S, Collier K (2004) Interaction of press and pulse disturbance on crayfish populations: flood impacts in pasture and forest streams. Hydrobiologia 527:113-124

Peschel K, Norton RA, Scheu S, Mauran M (2006) Do oribatid mites live in enemy-free space? Evidence from feeding experiments with the predatory mite Pergamasus septentrionalis. Soil Biol Biochem 38:2985-2989

Peterson CH, Black R (1988) Density-dependent mortality caused by physical stress interacting with biotic history. Am Nat 131:257-270

Rey D, Long A, Pautou MP, Meyran JC (1998) Comparative histopathology of some Diptera and Crustacea of aquatic alpine ecosystems, after treatment with Bacillus thuringiensis var. israelensis. Entomol Exp Appl 88:255-263

Rose RI (2001) Pesticides and public health: integrated methods of mosquito management. Emerg Infect Dis 7:17-23

Russell TL, Kay BH (2008) Biologically based insecticides for the control of immature Australian mosquitoes: a review. Aust J Entomol 47:232-242
Schneider K, Renker C, Scheu S, Maraun M (2004) Feeding biology of oribatid mites: a minireview. Phytophaga 14: 247-256

Skilleter GA (1996) An experimental test of artifacts from repeated sampling in soft-sediments. J Exp Mar Biol Ecol 205:137-148

Tanser F, Sharp B, le Sueur D (2003) Potential effect of climate change on malaria transmission in Africa. Lancet 362: 1792-1798

Templeton NS, Laufer H (1983) The effects of a juvenile hormone analogue (Altosid ZR-515) on the reproduction and development of Daphnia magna (Crustacea: Cladocera). Int J Invertebr Repr 6:99-110

Thomas BE, Connolly RM (2001) Fish use of subtropical saltmarshes in Queensland, Australia: relationships with vegetation, water depth and disturbance onto the marsh. Mar Ecol Prog Ser 209:275-288

Underwood AJ (1989) The analysis of stress in natural populations. Biol J Linn Soc 37:51-78

Underwood AJ (1995) Toxicological testing in laboratories is not ecological testing of toxicology. Hum Ecol Risk Assess $1: 178-182$

Underwood AJ (1997) Experiments in ecology: their logical design and interpretation using analysis of variance. Cambridge University Press, London

Walter DE, Proctor HC (1999) Mites: ecology, evolution and behavior. University of New South Wales Press, Sydney

> Ward DV, Howes BL, Ludwig DF (1976) Interactive effects of predation pressure and insecticide (Temefos) toxicity on populations of the marsh fiddler crab Uca pugnax. Mar Biol 35:119-126

Appendix 1. Table A1. Differences in community composition between treated (Bti and s-methoprene) and control plots, compared with non-parametric permutational multivariate ANOVA (PERMANOVA). Data were 4th-root transformed and analysis was based on the Bray-Curtis similarity measure. ${ }^{*}$ Significant at $\mathrm{p}<0.05$

\begin{tabular}{|c|c|c|c|c|c|c|c|}
\hline \multirow[b]{2}{*}{ Sample type } & \multicolumn{3}{|c|}{$\longrightarrow \mathrm{p}$ (PERMANOVA) } & \multirow[b]{2}{*}{ Day 1} & \multicolumn{2}{|c|}{ p (pair-wise a posteriori) } & \multirow[b]{2}{*}{ Day 20} \\
\hline & Treatment & Time & Interaction & & Day $4 / 5^{a}$ & Day 8 & \\
\hline \multicolumn{8}{|l|}{ Bti } \\
\hline \multicolumn{8}{|c|}{ Coomera Waters } \\
\hline Aspirator & $0.003^{*}$ & $0.001^{*}$ & 0.963 & 0.621 & 0.080 & 0.379 & 0.525 \\
\hline Pit-fall & $0.031^{*}$ & $0.001^{*}$ & $0.018^{*}$ & 0.095 & $0.047^{*}$ & 0.430 & 0.409 \\
\hline Sweep net & $0.001^{*}$ & $0.001^{*}$ & $0.001^{*}$ & $0.005^{*}$ & 0.117 & - & - \\
\hline \multicolumn{8}{|c|}{ Garden Island } \\
\hline Aspirator & 0.963 & $0.001^{*}$ & 0.096 & - & - & - & \\
\hline Pit-fall & 0.695 & $0.001^{*}$ & 0.973 & - & - & - & - \\
\hline Sweep net & $0.025^{*}$ & $0.001^{*}$ & $0.006^{*}$ & 0.355 & $0.013^{*}$ & - & - \\
\hline \multicolumn{8}{|c|}{$\begin{array}{l}S \text {-methoprene } \\
\text { Coomera Waters }\end{array}$} \\
\hline Aspirator & 0.244 & $0.001^{*}$ & 0.373 & - & - & - & - \\
\hline Pit-fall & $0.007^{*}$ & $0.001^{*}$ & 0.059 & 0.222 & 0.106 & 0.204 & 0.067 \\
\hline Sweep net & $0.004^{*}$ & $0.014^{*}$ & 0.129 & 0.065 & 0.441 & - & - \\
\hline \multicolumn{8}{|c|}{ Garden Island } \\
\hline Aspirator & 0.729 & 0.063 & 0.541 & - & - & - & - \\
\hline Pit-fall & 0.766 & $0.001^{*}$ & $0.031^{*}$ & 0.348 & 0.625 & 0.382 & 0.521 \\
\hline Sweep net & 0.768 & $0.001^{*}$ & $0.005^{*}$ & 0.090 & 0.219 & - & - \\
\hline
\end{tabular}


Table A2. Differences in abundance of individual taxa (that contributed $>10 \%$ to the community composition) between treated (Bti and s-methoprene) and control plots, compared with univariate 2-way ANOVA (using STATISTICA). s-meth: s-methoprene; CW: Coomera Waters; GI: Garden Island; A: aspirator; PF: pit-fall trap; SN: aquatic sweep net. Data were natural log-transformed where necessary to meet the assumptions of homoscedasticity after Cochran's test. ${ }^{*}$ Significant at $\mathrm{p}<0.05$

\begin{tabular}{|c|c|c|c|c|c|c|}
\hline Taxa & Treatment & Locality & Sample & Treatment & Time & Interaction \\
\hline Total individuals & $s$-meth & $\begin{array}{l}\text { CW } \\
\text { GI } \\
\text { CW } \\
\text { GI }\end{array}$ & $\begin{array}{c}\text { A } \\
\mathrm{PF} \\
\mathrm{SN} \\
\mathrm{A} \\
\mathrm{PF} \\
\mathrm{SN} \\
\mathrm{A} \\
\mathrm{PF} \\
\mathrm{SN} \\
\mathrm{A} \\
\mathrm{PF} \\
\mathrm{SN}\end{array}$ & $\begin{array}{l}0.392 \\
0.848 \\
0.923 \\
0.990 \\
0.812 \\
0.004^{*} \\
0.924 \\
0.432 \\
0.066 \\
0.367 \\
0.658 \\
0.723\end{array}$ & $\begin{array}{r}0.002^{*} \\
0.027^{*} \\
0.727 \\
0.001^{*} \\
<0.001^{*} \\
0.001^{*} \\
0.023^{*} \\
<0.001^{*} \\
0.054 \\
0.025^{*} \\
0.001^{*} \\
<0.001^{*}\end{array}$ & $\begin{array}{l}0.815 \\
0.192 \\
0.021^{*} \\
0.965 \\
0.916 \\
0.035^{*} \\
0.436 \\
0.328 \\
0.294 \\
0.842 \\
0.965 \\
0.031^{*}\end{array}$ \\
\hline Adult Diptera & $\begin{array}{c}\text { Bti } \\
\text { s-meth }\end{array}$ & $\begin{array}{l}\text { CW } \\
\text { GI } \\
\text { CW } \\
\text { GI }\end{array}$ & $\begin{array}{c}\text { A } \\
\text { A } \\
\text { PF } \\
\text { A } \\
\text { A }\end{array}$ & $\begin{array}{l}0.598 \\
0.826 \\
0.787 \\
0.093 \\
0.510\end{array}$ & $\begin{array}{l}0.275 \\
0.003^{*} \\
0.015^{*} \\
0.029^{*} \\
0.045^{*}\end{array}$ & $\begin{array}{l}0.842 \\
0.981 \\
0.846 \\
0.707 \\
0.857\end{array}$ \\
\hline Heteroptera & $\begin{array}{c}\text { Bti } \\
\text { s-meth }\end{array}$ & $\begin{array}{l}\text { CW } \\
\text { CW } \\
\text { GI }\end{array}$ & $\begin{array}{c}\mathrm{A} \\
\mathrm{PF} \\
\mathrm{A} \\
\mathrm{PF} \\
\mathrm{PF}\end{array}$ & $\begin{array}{l}0.051 \\
0.870 \\
0.794 \\
0.366 \\
0.721\end{array}$ & $\begin{array}{c}0.081 \\
<0.001^{*} \\
0.459 \\
<0.001^{*} \\
0.029^{*}\end{array}$ & $\begin{array}{l}0.765 \\
0.002^{*} \\
0.477 \\
0.815 \\
0.162\end{array}$ \\
\hline Hymenoptera & $\begin{array}{c}\text { Bti } \\
s \text {-meth }\end{array}$ & $\begin{array}{l}\text { CW } \\
\text { CW } \\
\text { GI }\end{array}$ & $\begin{array}{l}\text { A } \\
\text { PF } \\
\text { PF } \\
\text { PF }\end{array}$ & $\begin{array}{l}0.792 \\
0.690 \\
0.822 \\
0.955\end{array}$ & $\begin{array}{r}<0.001^{*} \\
0.011^{*} \\
0.009^{*} \\
0.044^{*}\end{array}$ & $\begin{array}{l}0.908 \\
0.318 \\
0.120 \\
0.954\end{array}$ \\
\hline Collembola & $\begin{array}{c}B t i \\
\text { s-meth }\end{array}$ & $\begin{array}{c}\mathrm{CW} \\
\mathrm{CW} \\
\mathrm{GI}\end{array}$ & $\begin{array}{l}\mathrm{PF} \\
\mathrm{PF} \\
\mathrm{PF}\end{array}$ & $\begin{array}{l}0.776 \\
0.028^{*} \\
0.030^{*}\end{array}$ & $\begin{array}{c}0.042^{*} \\
<0.001^{*} \\
0.219\end{array}$ & $\begin{array}{l}0.336 \\
0.524 \\
0.496\end{array}$ \\
\hline Acariformes & $\begin{array}{c}\text { Bti } \\
\text { s-meth }\end{array}$ & $\begin{array}{l}\text { CW } \\
\text { CW } \\
\text { GI }\end{array}$ & $\begin{array}{c}\text { A } \\
\text { PF } \\
\text { A } \\
\text { PF } \\
\text { A } \\
\text { PF }\end{array}$ & $\begin{array}{c}0.477 \\
<0.001^{*} \\
0.023^{*} \\
0.257 \\
0.007^{*} \\
0.078\end{array}$ & $\begin{array}{c}0.100 \\
0.175 \\
<0.001^{*} \\
<0.001^{*} \\
0.084 \\
0.785\end{array}$ & $\begin{array}{l}0.606 \\
0.022^{*} \\
0.716 \\
0.307 \\
0.270 \\
0.086\end{array}$ \\
\hline Araneae & $B t i$ & GI & $\mathrm{PF}$ & 0.828 & $<0.001^{*}$ & 0.897 \\
\hline Copepoda & $\begin{array}{c}\text { Bti } \\
\text { s-meth }\end{array}$ & $\begin{array}{l}\text { CW } \\
\text { GI } \\
\text { CW } \\
\text { GI }\end{array}$ & $\begin{array}{l}\text { SN } \\
\text { SN } \\
\text { SN } \\
\text { SN }\end{array}$ & $\begin{array}{l}0.901 \\
0.003^{*} \\
0.065 \\
0.748\end{array}$ & $\begin{array}{c}0.716 \\
0.003^{*} \\
0.054 \\
<0.001^{*}\end{array}$ & $\begin{array}{l}0.021^{*} \\
0.057 \\
0.285 \\
0.034^{*}\end{array}$ \\
\hline Grapsidae & $B t i$ & GI & $\mathrm{PF}$ & 0.960 & $<0.001^{*}$ & 0.914 \\
\hline
\end{tabular}




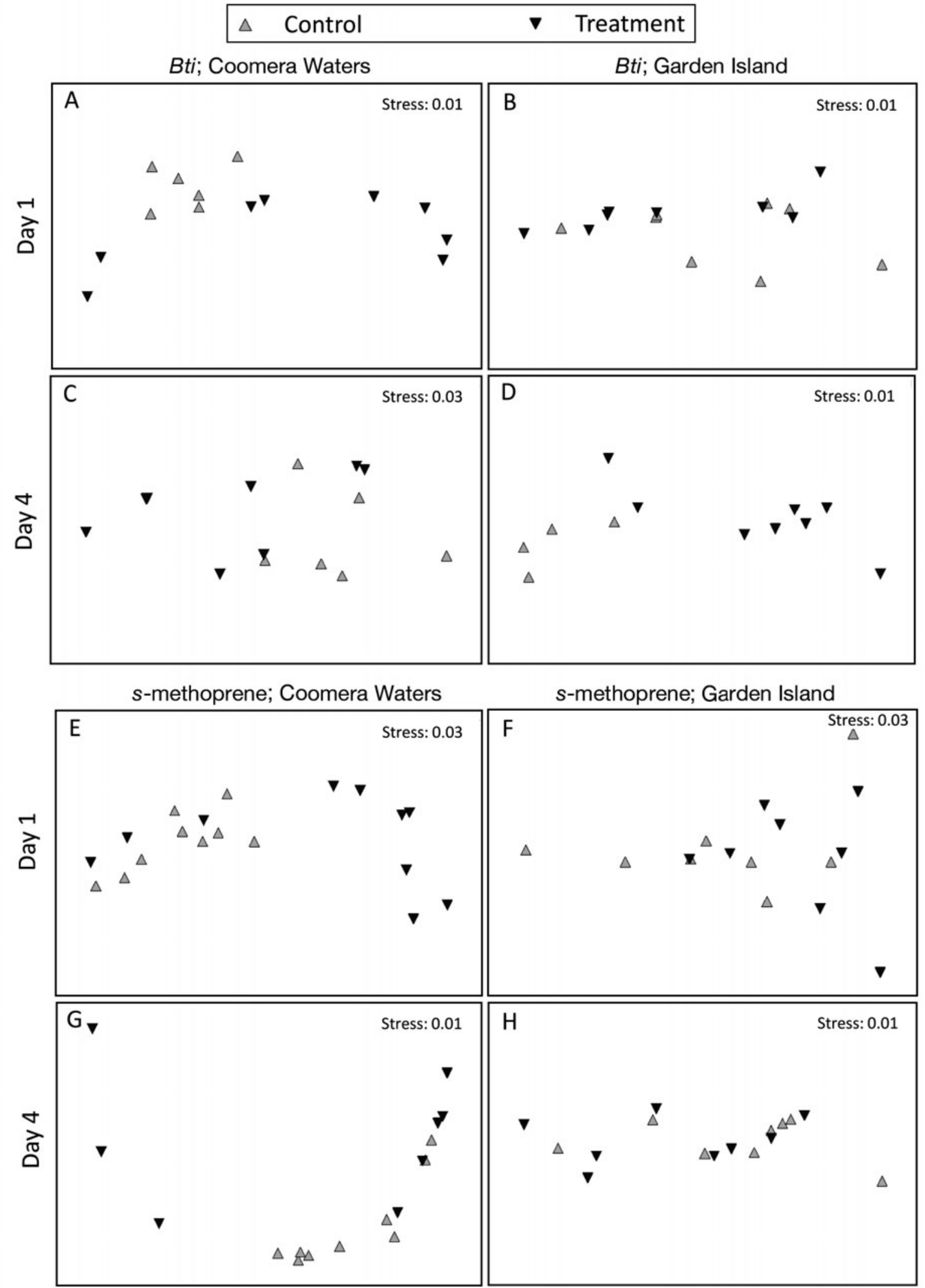

Fig. A1. Non-metric multidimensional scaling ordinations on 4th-root transformed species abundance data based on the BrayCurtis similarity measure from replicate samples from Bti $(\mathrm{A}-\mathrm{D})$ and $s$-methoprene $(\mathrm{E}-\mathrm{H})$ treated and control plots at Coomera Waters $(\mathrm{A}, \mathrm{C}, \mathrm{E}, \mathrm{G})$ and Garden Island $(\mathrm{B}, \mathrm{D}, \mathrm{F}, \mathrm{H})$ 